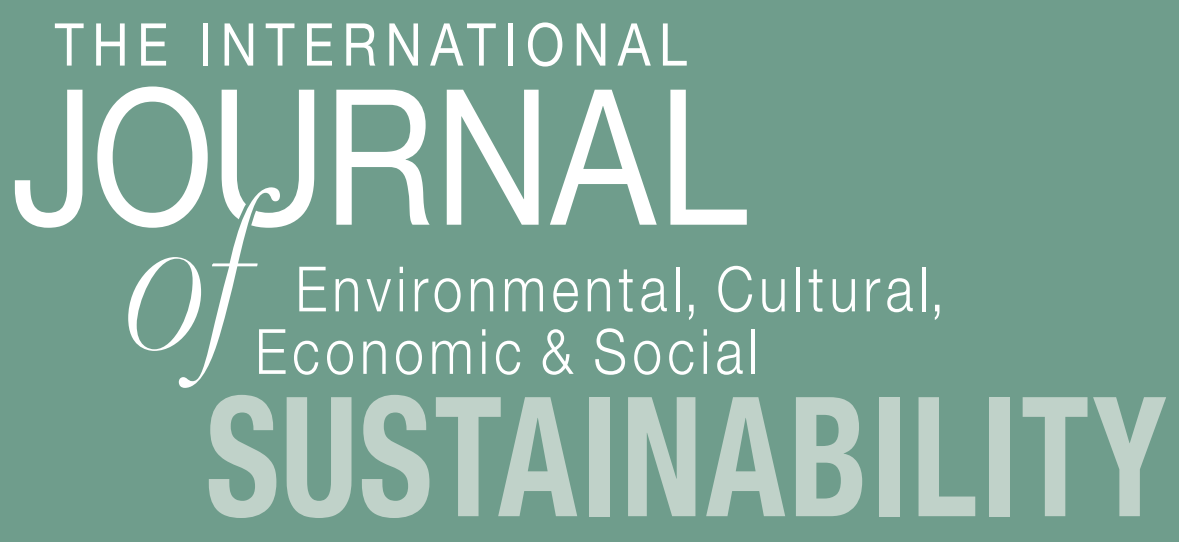

Volume 7 , Issue 4

Shopping to Save the Planet? Implicit Rather than Explicit Attitudes Predict Low Carbon Footprint Consumer Choice

Geoffrey Beattie and Laura Sale 
THE INTERNATIONAL JOURNAL OF ENVIRONMENTAL, CULTURAL, ECONOMIC AND SOCIAL SUSTAINABILITY

http://www.Sustainability-Journal.com

First published in 2011 in Champaign, Illinois, USA

by Common Ground Publishing LLC

www.CommonGroundPublishing.com

ISSN: $1832-2077$

(C) 2011 (individual papers), the author(s)

(c) 2011 (selection and editorial matter) Common Ground

All rights reserved. Apart from fair dealing for the purposes of study, research, criticism or review as permitted under the applicable copyright legislation, no part of this work may be reproduced by any process without written permission from the publisher. For permissions and other inquiries, please contact

<cg-support@commongroundpublishing.com>.

THE INTERNATIONAL JOURNAL OF ENVIRONMENTAL, CULTURAL, ECONOMIC AND SOCIAL SUSTAINABILITY is peer-reviewed, supported by rigorous processes of criterion-referenced article ranking and qualitative commentary, ensuring that only intellectual work of the greatest substance and highest significance is published.

Typeset in Common Ground Markup Language using CGPublisher multichannel typesetting system

http://www.commongroundpublishing.com/software/ 


\title{
Shopping to Save the Planet? Implicit Rather than Explicit Attitudes Predict Low Carbon Footprint Consumer Choice
}

\author{
Geoffrey Beattie, University of Manchester, UK \\ Laura Sale, University of Manchester, UK
}

\begin{abstract}
Climate change is upon us and requires urgent action. This has led to carbon footprint information appearing on products. But are consumers primed to change their behaviour? What is their fundamental attitude to low carbon products? And what attitudes might predict actual consumer behaviour? This study found that whilst most participants were pro-low carbon on both the explicit and implicit measures, the explicit and implicit scores did not themselves correlate. In addition, a number of participants scored significantly more positively on explicit than implicit measures, reflecting the social desirability of being seen as green. Neither of the explicit measures significantly differentiated the choice of high/low carbon products but the implicit measure did. Furthermore, it appears that when under time pressure, people seem to rely on their underlying implicit attitude to guide their consumer choices. Thus, it could be argued that if we are to genuinely engineer a green revolution, then we must augment these implicit attitudes and ensure that they translate to actual behaviour, for example, by designing carbon footprint 'signals' aimed primarily at the implicit system.
\end{abstract}

Keywords: Implicit Attitudes, Explicit Attitudes, Carbon Footprint, Carbon Labelling, Sustainability

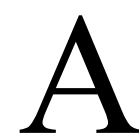

SLOW BUT accelerating change in our climate is occurring (Walker \& King, 2008) and there is no longer serious disagreement within the scientific community on the matter (see Beattie, 2010). It is now generally accepted that as human beings our patterns of consumption have been a major contributing factor, causing irreparable damage to our environment and climate (see, for example, the Stern Review, 2006). The recommendations of the World Bank's Annual World Development Report (2010) are sharp and to the point, 'We must act now, because what we do today determines both the climate of tomorrow and the choices that shape our future' (p.xiii). But where is this action supposed to come from? Is it to come primarily from governments who can develop and enact greener policies? Or is it to come primarily from individuals who will somehow 'voluntarily' modify their own individual behaviour? Despite this clarion call to action, significant behavioural change may be far from straightforward. As Walker and King (2008) have noted, 'It's easy to believe that global warming is somebody else's problem - other people will suffer and other people will come up with the solution' (p.238), yet they are adamant about where the real solution lies, 'it's as individuals that we live our lives and make our choices...now we will have to adapt our choices to the new realities of the twenty-first century' (p.238).

Choice, and what governs it, is an absolutely critical issue here. It has, for example, been argued that 'Individuals, as citizens and consumers, will determine the planet's future. Al-

The International Journal of Environmental, Cultural, Economic and Social Sustainability Volume 7, Issue 4, 2011, http://www.Sustainability-Journal.com, ISSN 1832-2077 
though an increasing number of people know about climate change and believe action is needed, too few make it a priority, and too many fail to act when they have the opportunity' (World Development Report 2010, p.xxi). So the question becomes why do so many people not make it a priority even when they could, for example, by modifying their everyday patterns of consumption or, alternatively, by limiting their overall patterns of consumption. By changing our everyday patterns of consumption we could make a very real difference. Focusing exclusively on the UK for the moment, Forum for the Future (2007) has highlighted that 'Retail has a vital role to play in delivering sustainable development. It is responsible for approximately $2.5 \%$ of the UK's carbon dioxide emissions and has a disproportionate influence over society and the economy through its marketing, regular customer transactions and complex, globalised supply chains' (p.8). In short, if we could achieve a revolution in green consumption in the UK and elsewhere, we would be one step closer to mitigating climate change.

An assumption underlying such activity is that consumers will act in an appropriately sustainable manner, provided they are given the information and the opportunity to make these sustainable choices in the first place (Sustainable Consumption Roundtable, 2006). Thus, carbon footprint information now appears on a number of commercial products such as light bulbs, detergent, and orange juice (although whether this information is scanned in the relevant time frame for a typical shopping decision is another issue, see Beattie, McGuire $\&$ Sale, 2010). Unfortunately, the inclusion of this information has not necessarily resulted in actual changes in the patterns of consumption towards the low carbon alternative (see the University of Manchester's Sustainable Consumption Institute Report, 'Consumers, Business and Climate Change', 2009). Perhaps, it is important to recall Gifford's (2008) warning that 'individuals truly are the ultimate key to climate-change amelioration: policies, programmes, and regulations themselves do not change anything. For one thing, to be acceptable and efficacious to individuals; policies must be "bought into" by individuals. In short, policy beckons or even commands, but persons accept or refuse its demands. Behavioural change does not occur until this happens' (p.2). If consumer choice really is the key to mitigating climate change then we need to determine urgently whether we, as individuals, are ready to buy into low carbon consumption.

Psychology seems to have been inordinately quiet on the issue despite there being a great deal of complex psychology underpinning the actual behaviour of consumer choice. Indeed, human beings have all kinds of predispositions to select one thing rather than another based on their underlying attitudes and beliefs, their habits, what they think others might do in the same situation and a host of other factors, some personal, some social, some economic, some specific, and others quite general. Additionally, there may well be a number of psychological barriers to individual action, ranging from selfish or self-centred action in the prisoners' dilemma sense ('it's up to others to do something about climate change'), through to a negative underlying attitude towards sustainability in the first place. It is essential that we fully understand the psyche of the consumer if we are to change patterns of consumption in a meaningful way. Psychology could hold the key.

In a different domain, market research seems to suggest that people are indeed 'primed' and ready to act in a more sustainable way. In a UK based sample, $78 \%$ of people said they would actually be prepared to 'do more and go further' by making changes to their lifestyles and patterns of behaviour. However, $76 \%$ of people admitted to being confused about which products they should be buying in order to be more environmentally friendly, and $78 \%$ felt 
that companies need to make it easier for consumers to buy environmentally friendly products (Downing \& Ballantyne, 2007). If we take these statistics at face value it would appear that attitudes towards sustainability are already very positive. But, of course, there is one rather large fly in the ointment. The exclusive focus of research in this area has been on explicit attitudes which necessarily introduce a major issue of social desirability. Everybody in our society knows that green is good and that people who are 'environmentally friendly' are almost certainly going to be perceived positively. Indeed, we now know that 'environmentally friendly' individuals are viewed as being 'considerate', 'thoughtful', 'caring', 'knowledgeable', 'selfless' and 'nice' (see Beattie, 2010). The problem with this, of course, is that social desirability, which is obviously very widespread throughout society, could be affecting the expression of explicit attitudes towards environmental behaviour. A major question is whether we can actually trust self-report measures in this sensitive domain; an assumption that until now has rarely been challenged. Research from elsewhere in psychology over the past few decades has revealed that there is often much more to an attitude than what a person actually says. Some have argued that much of our 'attitudinal readiness to act' is, in fact, unconscious and not reportable in the normal way (and therefore implicit), and that this unconscious component of the attitude may not relate closely to the component which is available to conscious reflection (Greenwald \& Banaji, 1995). Indeed, some have argued that the human mind can be divided into two largely independent subsystems; a familiar foreground where processing is conscious, controlled, reflective, intentional and slow (characteristic of the explicit attitude), and a hidden background harbouring our implicit attitudes where processing is unconscious, automatic, impulsive, unintended and fast (Gregg, 2008). These implicit attitudes may have a major impact on the everyday behaviour of consumers in a range of contexts.

With the introduction of the Implicit Association Test (IAT) by Greenwald, McGhee and Schwartz in 1998, the technology became available to lay bare some of these unconscious processes. The IAT is a computerised classification task that is acknowledged as a reliable and valid measure of implicit attitudes towards a given target concept. The basic premise behind the IAT is that when categorising items into two sets of paired concepts, if the concepts are strongly associated, then participants should be able to categorise items faster (and with fewer errors) into these sets than if they are not strongly associated.

Few studies have attempted to measure implicit attitudes in the domain of sustainability (but see Beattie \& Sale, 2009; Vantomme, Geuens, De Houwer \& De Pelsmacker, 2005). In the first investigation into explicit and implicit attitudes towards carbon footprint, Beattie and Sale (2009) created a carbon footprint version of the IAT that compared the categories of high and low carbon footprint products with the attributes 'good' and 'bad'. The carbon footprint IAT revealed that in a sample of UK consumers in 2008, most participants showed a positive implicit attitude towards low carbon footprint products (although this was just one preliminary sample). However, there was another significant feature of this particular dataset, namely that there was no significant correlation between the explicit and implicit scores. In other words, the explicit and implicit attitudes appeared to be 'dissociated' with a significant proportion of individuals appearing to be much more pro-low carbon on the explicit measure than they were on the implicit measure (and vice versa). This was the first experimental indication that some people may well be exaggerating their green credentials (and indeed some seemed to do the opposite by underestimating their own 'green' beliefs, although the reason for doing this is much less clear; perhaps they genuinely did not know what their 'real' im- 
plicit attitude actually was). The emergence of such attitudinal divergence is not unusual in light of previous attitude research. We already know from a number of other domains that implicit attitudes may not relate that closely to reported explicit attitudes. Nosek and Hansen (2008) reported that in a meta-analysis of 81 studies, implicit attitudes were only moderately correlated with self-reported attitudes $(r=0.24$; Hofmann, Gawronski, Gschwendner, Le \& Schmitt, 2005), and in a study of 50 attitude domains, Nosek (2005) found that the strength of the correlation between the IAT scores and self-reported attitudes varied from near zero for some attitude domains (e.g. attitudes to 'fat' and 'thin'), to approximately 0.70 in other domains (e.g. 'pro-choice' and 'pro-life' attitudes). So in the words of Greenwald and Nosek (2008), there is, at the very least, something of a 'mundane dissociation' between the two constructs. But just how significant this 'dissociation' actually is remains to be seen (as do the potential implications of a real dissociation in this specific domain). Elsewhere, some have argued (the 'single representation' hypothesis) that the appearance of a dissociation between explicit and implicit attitudes is just an illusion and that, in self-report measures, participants simply have the opportunity to modify their real response in their explicit reporting of their attitude. But others argue (the 'dual representation' hypothesis) that explicit and implicit measures of attitude have structurally distinct mental representations and are genuinely dissociated (see Chaiken \& Trope 1999; Wilson, Lindsey \& Schooler, 2000). Research has not currently decided between these two alternatives. But just imagine if this 'unconscious, automatic, unintended, impulsive and fast' system (the implicit one) came to very different, and much more negative, conclusions about carbon footprint information and the environment than our conscious and reflective system. Where would that leave the whole philosophy of carbon labelling and the role of consumer choice in the sustainability agenda (and maybe even the survival of the planet)?

The relationship between explicit and implicit attitudes is clearly a major issue for social psychology and for those wishing to promote behavioural change in many core areas. Greenwald, Poehlman, Uhlmann and Banaji (2009) conducted a meta-analysis on the predictive validity of the IAT and concluded that, in general, when explicit attitude measures and the IAT are combined, they are together better predictors of behaviour than either measure alone. However, when attitudes are 'socially sensitive', and where social desirability concerns are inevitably present (as in attitudes to race, age, gender or the environment) then explicit measures are very poor predictors of behaviour, and in these situations the IAT would appear to be a much better predictor of behaviour than explicit measures. More recently, Greenwald along with other researchers have started to apply the IAT to consumer research since it has become increasingly apparent that consumer behaviour does not necessarily involve conscious and rational decision-making, but can also be influenced by all sorts of unconscious factors as well as mere habit. You can often see people in the supermarket picking up products without even properly looking at them, let alone making complex decisions based upon price or nutritional value or fat content. There might well be something at work here which is not based upon conscious, reflective, rational thought and slow decision making. Table 1 has been adapted from the meta-analysis conducted by Greenwald et al. (2009) to outline the fifteen published studies that have used the IAT in the consumer domain. 
Table 1: The IAT as a Potential Predictor of Consumer Behaviour

\begin{tabular}{|c|c|c|}
\hline Citation & Behavioural Measure & $\begin{array}{l}\text { Did the IAT successfully predict } \\
\text { behaviour? }\end{array}$ \\
\hline $\begin{array}{l}\text { Brunel, Tietje } \\
\text { and Greenwald } \\
(2004)\end{array}$ & $\begin{array}{l}\text { Study 1: Self-report of owner- } \\
\text { ship and usage frequency of } \\
\text { Mac and PC. }\end{array}$ & $\begin{array}{l}\text { Both the IAT and explicit attitude measure } \\
\text { predicted ownership and usage. }\end{array}$ \\
\hline $\begin{array}{l}\text { Friese, } \\
\text { Hofmann and } \\
\text { Wänke (2008) }\end{array}$ & $\begin{array}{l}\text { Study 1: Behavioural choice } \\
\text { task between apples and } \\
\text { chocolate where working } \\
\text { memory capacity was reduced. }\end{array}$ & $\begin{array}{l}\text { When processing resources are 'ample', } \\
\text { the explicit attitude measure is a better } \\
\text { predictor of behaviour. When processing } \\
\text { resources are 'taxed', 'behaviour appeared } \\
\text { to be more strongly driven by impulsive } \\
\text { processes as indicated by the increase in } \\
\text { the implicit measure's predictive validity.' }\end{array}$ \\
\hline $\begin{array}{l}\text { Friese, } \\
\text { Hofmann and } \\
\text { Wänke (2008) }\end{array}$ & $\begin{array}{l}\text { Study 2: Consumption of potato } \\
\text { crisps after watching a film } \\
\text { where emotions were either } \\
\text { controlled, depleting 'self-regu- } \\
\text { latory strength', or not con- } \\
\text { trolled. }\end{array}$ & $\begin{array}{l}\text { '... when participants were depleted of their } \\
\text { self-regulatory strength [by having to sup- } \\
\text { press their emotional response to a film], } \\
\text { not only did the implicit measure gain } \\
\text { considerable predictive power compared } \\
\text { with the control condition but also the ex- } \\
\text { plicit measure was now unrelated to potato } \\
\text { crisps consumption.' }\end{array}$ \\
\hline $\begin{array}{l}\text { Friese, } \\
\text { Hofmann and } \\
\text { Wänke (2008) }\end{array}$ & $\begin{array}{l}\text { Study 3: Beer consumption } \\
\text { after watching a film where } \\
\text { emotions were either controlled } \\
\text { (depleting 'self-regulatory } \\
\text { strength') or not controlled. }\end{array}$ & $\begin{array}{l}\text { 'When resources were scarce [because } \\
\text { participants had to suppress their emotional } \\
\text { response to a film] the implicit measure } \\
\text { predicted behaviour well and showed incre- } \\
\text { mental validity over and above both expli- } \\
\text { cit self-report measures at the same time.' }\end{array}$ \\
\hline $\begin{array}{l}\text { Friese, Wänke } \\
\text { and Plessner } \\
(2006)\end{array}$ & $\begin{array}{l}\text { Brand choice between generic } \\
\text { or branded products in experi- } \\
\text { mental conditions either under } \\
\text { time pressure [ } 5 \text { seconds to } \\
\text { make their choice], or not under } \\
\text { time pressure [unlimited time]. }\end{array}$ & $\begin{array}{l}\text { 'Participants whose explicit and implicit } \\
\text { preferences regarding generic food } \\
\text { products and well-known food brands were } \\
\text { incongruent were more likely to choose the } \\
\text { implicitly preferred brand over the expli- } \\
\text { citly preferred one when choices were } \\
\text { made under time pressure. The opposite } \\
\text { was the case when they had ample time to } \\
\text { make their choice.' }\end{array}$ \\
\hline
\end{tabular}




\begin{tabular}{|c|c|c|}
\hline Gibson (2008) & $\begin{array}{l}\text { Brand choice between Coke or } \\
\text { Pepsi in experimental condi- } \\
\text { tions when cognitive load was } \\
\text { manipulated (by asking parti- } \\
\text { cipants to remember an } 8 \text { digit } \\
\text { number, or not). }\end{array}$ & $\begin{array}{l}\text { '...choice in this high load condition was } \\
\text { related to implicit attitudes, while choice } \\
\text { in the low load condition was not.' }\end{array}$ \\
\hline $\begin{array}{l}\text { Hofmann and } \\
\text { Friese (2008) }\end{array}$ & $\begin{array}{l}\text { Candy consumption when parti- } \\
\text { cipants had been drinking alco- } \\
\text { hol or not. }\end{array}$ & $\begin{array}{l}\text { 'Specifically, the predictive validity of } \\
\text { implicit attitudes (as part of the impulsive } \\
\text { system) was markedly increased for parti- } \\
\text { cipants who had consumed alcohol as } \\
\text { compared with sober participants.' }\end{array}$ \\
\hline $\begin{array}{l}\text { Hofmann, } \\
\text { Rauch and } \\
\text { Gawronski } \\
(2007)\end{array}$ & $\begin{array}{l}\text { Candy consumption after } \\
\text { watching a film and being } \\
\text { asked to either suppress emo- } \\
\text { tions (depletion condition) or } \\
\text { 'let emotions flow' (control } \\
\text { condition). }\end{array}$ & $\begin{array}{l}\text { '...automatic candy attitudes showed a } \\
\text { positive correlation to candy consumption } \\
\text { in the depletion condition but not in the } \\
\text { control condition. That is, candy consump- } \\
\text { tion significantly increased as a function } \\
\text { of automatic positivity toward the candy } \\
\text { in the depletion condition but not in the } \\
\text { control condition.' }\end{array}$ \\
\hline $\begin{array}{l}\text { Karpinski and } \\
\text { Hilton (2001) }\end{array}$ & $\begin{array}{l}\text { Study 2: Behavioural choice } \\
\text { between apples or candy bars. }\end{array}$ & $\begin{array}{l}\text { '...explicit attitudes and the IAT are inde- } \\
\text { pendent....explicit attitudes predicted beha- } \\
\text { viour but the IAT did not.' } \\
\text { (Note: there was no time pressure/drain on } \\
\text { cognitive resources etc. operating here. In } \\
\text { this study - participants 'were informed } \\
\text { that they could choose only one of the ob- } \\
\text { jects [apple or candy bar] to eat or to take } \\
\text { home with them.') }\end{array}$ \\
\hline $\begin{array}{l}\text { Karpinski and } \\
\text { Steinman } \\
(2006)\end{array}$ & $\begin{array}{l}\text { Study 1: Brand choice between } \\
\text { Coke or Pepsi. }\end{array}$ & $\begin{array}{l}\text { Both the IAT and explicit attitude measures } \\
\text { predicted choice of branded drink. }\end{array}$ \\
\hline $\begin{array}{l}\text { Karpinski, } \\
\text { Steinman and } \\
\text { Hilton }(2005)\end{array}$ & $\begin{array}{l}\text { Voting intention in the } 2000 \\
\text { United States presidential elec- } \\
\text { tion and also brand choice } \\
\text { between Coke or Pepsi. }\end{array}$ & $\begin{array}{l}\text { '...explicit attitude measures were better } \\
\text { predictors of deliberative behaviours than } \\
\text { IAT scores.' }\end{array}$ \\
\hline $\begin{array}{l}\text { Maison, } \\
\text { Greenwald and } \\
\text { Bruin }(2001)\end{array}$ & $\begin{array}{l}\text { Study 1: Self-reported drinking } \\
\text { of juices or soda, and self-repor- } \\
\text { ted dieting. }\end{array}$ & $\begin{array}{l}\text { '...both studies resulted in significant cor- } \\
\text { relation between the IAT and Ss' self-re- } \\
\text { ported behaviour.' }\end{array}$ \\
\hline $\begin{array}{l}\text { Maison, } \\
\text { Greenwald and } \\
\text { Bruin (2004) }\end{array}$ & $\begin{array}{l}\text { Study 1: Self-reported consump- } \\
\text { tion of yoghurt brands/eating at } \\
\text { different fast food restaur- } \\
\text { ants/consumption of Coke or } \\
\text { Pepsi. }\end{array}$ & $\begin{array}{l}\text { 'A meta-analytic combination of the three } \\
\text { studies showed that the use of IAT meas- } \\
\text { ures increased the prediction of behaviour } \\
\text { relative to explicit attitude measures alone.' }\end{array}$ \\
\hline
\end{tabular}




\begin{tabular}{|l|l|l|}
\hline $\begin{array}{l}\text { Olson and } \\
\text { Fazio (2004) }\end{array}$ & $\begin{array}{l}\text { Study 3: Self-reported beha- } \\
\text { viour of apple and candy bar } \\
\text { consumption. }\end{array}$ & $\begin{array}{l}\text { IAT predicted behaviour, particularly a } \\
\text { more personalized IAT, '..the personalized } \\
\text { IAT correlated more strongly with explicit } \\
\text { measures of liking, past eating behaviour, } \\
\text { and behavioural intentions than did the } \\
\text { traditional IAT.' }\end{array}$ \\
\hline $\begin{array}{l}\text { Scarabis, } \\
\text { Florack and } \\
\text { Gosejohann } \\
(2006)\end{array}$ & $\begin{array}{l}\text { Choice between chocolate and } \\
\text { fruit. }\end{array}$ & $\begin{array}{l}\text { The IAT was a good predictor of actual } \\
\text { choice, '...people rely more on automatic } \\
\text { preferences that are independent from } \\
\text { higher-order appraisals when they focus } \\
\text { on their affective responses [what enjoy- } \\
\text { ment they might get from the food] than } \\
\text { when they think about the advantages and } \\
\text { disadvantages of choice options.' }\end{array}$ \\
\hline $\begin{array}{l}\text { Swanson, } \\
\text { Rudman and } \\
\text { Greenwald } \\
(2001)\end{array}$ & $\begin{array}{l}\text { Study 2: Self-reported smoking } \\
\text { behaviour or vegetarian- } \\
\text { ism/non-vegetarianism. }\end{array}$ & $\begin{array}{l}\text { The IAT and explicit attitude measures did } \\
\text { predict vegetarianism/non-vegetarianism } \\
\text { but not smoking. }\end{array}$ \\
\hline $\begin{array}{l}\text { Vantomme, } \\
\text { Geuens, De } \\
\text { Houwer and De } \\
\text { Pelsmacker } \\
(2005)\end{array}$ & $\begin{array}{l}\text { Self-reported purchase inten- } \\
\text { tions for real and fictitious } \\
\text { brands of green and environ- } \\
\text { mentally unfriendly cleaning } \\
\text { products. }\end{array}$ & $\begin{array}{l}\text { 'The IAT, but not the explicit difference } \\
\text { score, differentiated between respondents } \\
\text { intending to buy the real ecological all- } \\
\text { purpose cleaner and those intending to buy } \\
\text { the real traditional all-purpose cleaner.' }\end{array}$ \\
\hline
\end{tabular}

These studies suggest a positive trend with respect to the predictive power of the IAT, particularly under certain types of conditions. When people are under any kind of time pressure, or when they are attempting to control their emotional state, or when they are under the influence of alcohol, the IAT seems to be a good predictor of behaviour. Explicit measures, on the other hand, are usually better when there is no mental load or time pressure, thereby allowing the person to make slower, deliberate and reflective behavioural decisions. Supermarket shopping, however, is often not a slow, deliberate, reflective process. The shopper passes about 300 brands per minute (Rundh, 2007) and each individual choice is often quick and automatic (Zeithaml, 2008). In such contexts, the IAT might well be a better predictor of consumer behaviour than a measure of explicit attitude.

Only one other study prior to Beattie and Sale (2009) had applied the IAT to the domain of sustainability. Vantomme et al. (2005) examined explicit and implicit attitudes towards green cleaning products and had expected to find that implicit attitudes would be less positive than the explicit attitudes because of social desirability. In their first experiment, fictitious cleaning products (in an attempt to avoid brand image impacting upon the results) were introduced to participants during a 'learning phase' where participants were informed that one product was environmentally friendly whilst the other was harmful to the environment. What 
they found, however, was that in contrast to their initial hypothesis, implicit attitudes towards the fictitious green cleaning products were far more positive than explicit attitudes. In a second experiment where real brands were used instead of fictitious products, they found no such difference in explicit and implicit attitudes towards the green cleaning products. As such, the results from this study are far from conclusive with respect to the underlying implicit attitudes that people might actually hold towards green products. Moreover, no study has attempted to compare the predictive value of measures of explicit and implicit attitudes to low carbon products for actual consumer choice.

Given the potential importance of this topic with respect to climate change, it is crucial to understand fully the nature of explicit and implicit attitudes towards green products. We need to understand this in order to assess consumers' willingness to change their patterns of consumption (given potentially the right kinds of triggers). The present study thus has two main goals, firstly to measure explicit and implicit attitudes to low carbon footprint products in a larger sample than previously used and secondly to employ a consumer choice paradigm to see which measure (explicit or implicit) differentiates the choice of high/low carbon products. An additional exploratory variable that will also be considered in the second study is time pressure. Given that, by nature, supermarket shopping may be conducted under a degree of time pressure, we will also explore the possible contribution of time pressure in consumer choice to understand what effect it may have on consumer choice (if any).

\section{Study 1}

\section{Method}

\section{Participants}

180 participants (including college and university students as well as academic and support staff at colleges and universities) were gathered through opportunity sampling. The first 100 participants were not paid for participating in the study, whereas the second set of 80 participants were paid $£ 5$ for taking part. Remuneration was necessary for the second set to complete the sample in a reasonable time frame (this had no discernible effect on the scores obtained; the means showed little variation and no scale boundaries were crossed). We wished to introduce a behavioural choice task (with the second set of 80 participants) but wanted to consider the explicit and implicit scores for the set as a whole (all 180 participants).

\section{Procedure}

\section{Explicit Attitude Measures}

Participants completed two computerised explicit attitude tests (Likert scale and feeling thermometer). The Likert scale assessed explicit preference towards high/low carbon footprint products. Participants were asked: 'Which statement best describes you?' on a 5-point scale ( 1 = I strongly prefer products with a high carbon footprint to a low carbon footprint'; $5=$ 'I strongly prefer products with a low carbon footprint to a high carbon footprint'). The feeling thermometer assessed explicit feelings of warmth and coldness towards products with high/low carbon footprints. Participants were asked: 'Please rate how warm or cold you feel towards the following products' (1 being 'very cold'; 5 being 'very warm'). Ther- 
mometer difference (TD) scores (ranging from -4 to +4 ) were calculated by subtracting the score given to the high carbon footprint product from the score given to the low. Positive scores indicated a preference for products with a low carbon footprint.

\section{Implicit Attitude Measure}

In the case of the IAT, there were two target categories (high/low carbon footprint) and two attribute categories (good/bad). Exemplars from these categories appeared in the middle of the screen and participants were asked to sort the exemplars into their respective categories which appeared at the top left and top right corners of the screen. The target categories of high/low carbon footprint were represented pictorially using photographs of various high/low carbon footprint products. The target categories of good or bad were represented using words with a positive valence to represent the concept of 'good' and words with a negative valence to represent the concept of 'bad'. There were seven trials where Blocks 1, 2 and 5 were practice trials and Blocks 3, 4, 6 and 7 were the critical trials where participants were required to sort exemplars into one of two categories that appeared simultaneously. IAT effect scores were computed using the algorithm originally devised by Greenwald, Nosek and Banaji (2003). The D score reflects the difference in latencies during the critical trials and the error rate. D score effect sizes are similar to Cohen's $d$ (Cohen, 1988) and usually take the form of small, medium and large values of $0.2,0.5$ and 0.8 respectively. Positive IAT effect scores reflect a preference for low carbon footprint products, whereas negative effect scores reflect a preference for high carbon footprint products (D scores between - 0.2 and +0.2 are considered neutral, indicating no preference for either high or low carbon products).

\section{Analysis}

Table 2 outlines the mean scores for the explicit attitudes measures and the implicit attitude measure.

Table 2: Mean Explicit and Implicit Scores

\begin{tabular}{|l|c|c|}
\hline & Mean & SD \\
\hline Likert Score & 3.84 & 0.87 \\
\hline TD Score & 1.66 & 1.68 \\
\hline D Score & 1.48 & 1.96 \\
\hline
\end{tabular}

The distribution of the explicit attitude measures and the implicit attitude measure are outlined in figures 1,2 and 3. 


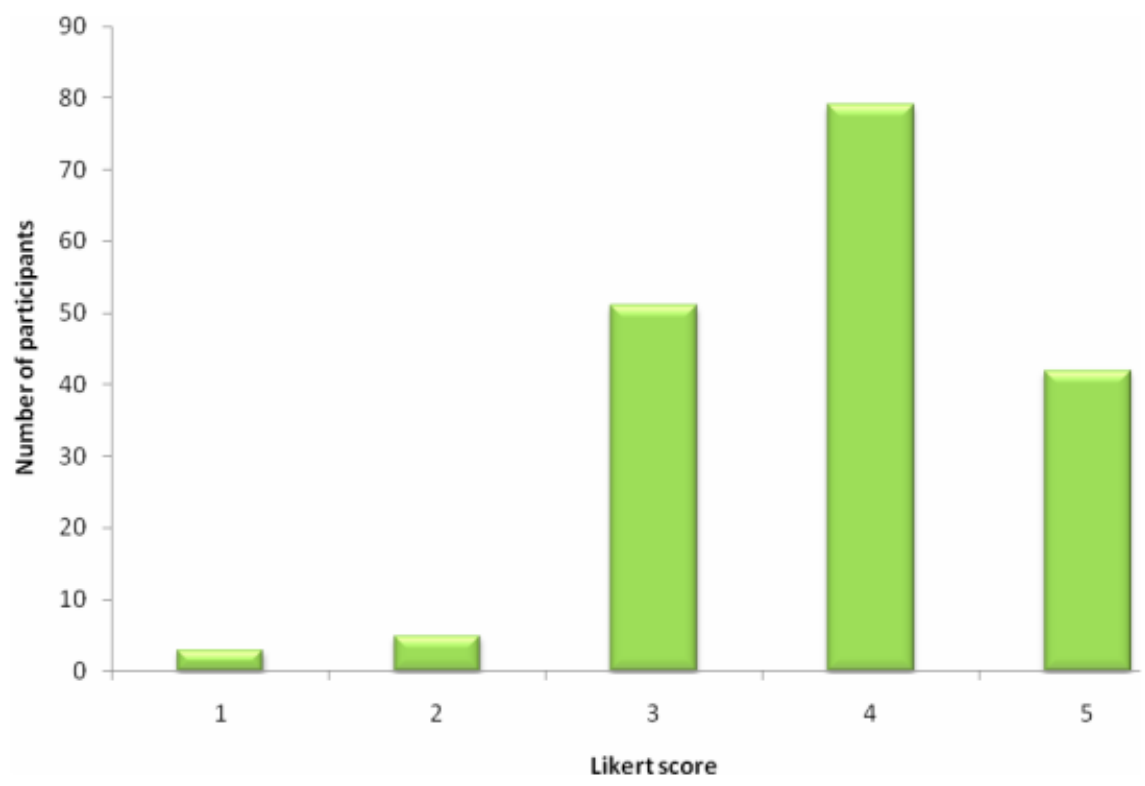

Figure 1: Distribution of Likert Scores

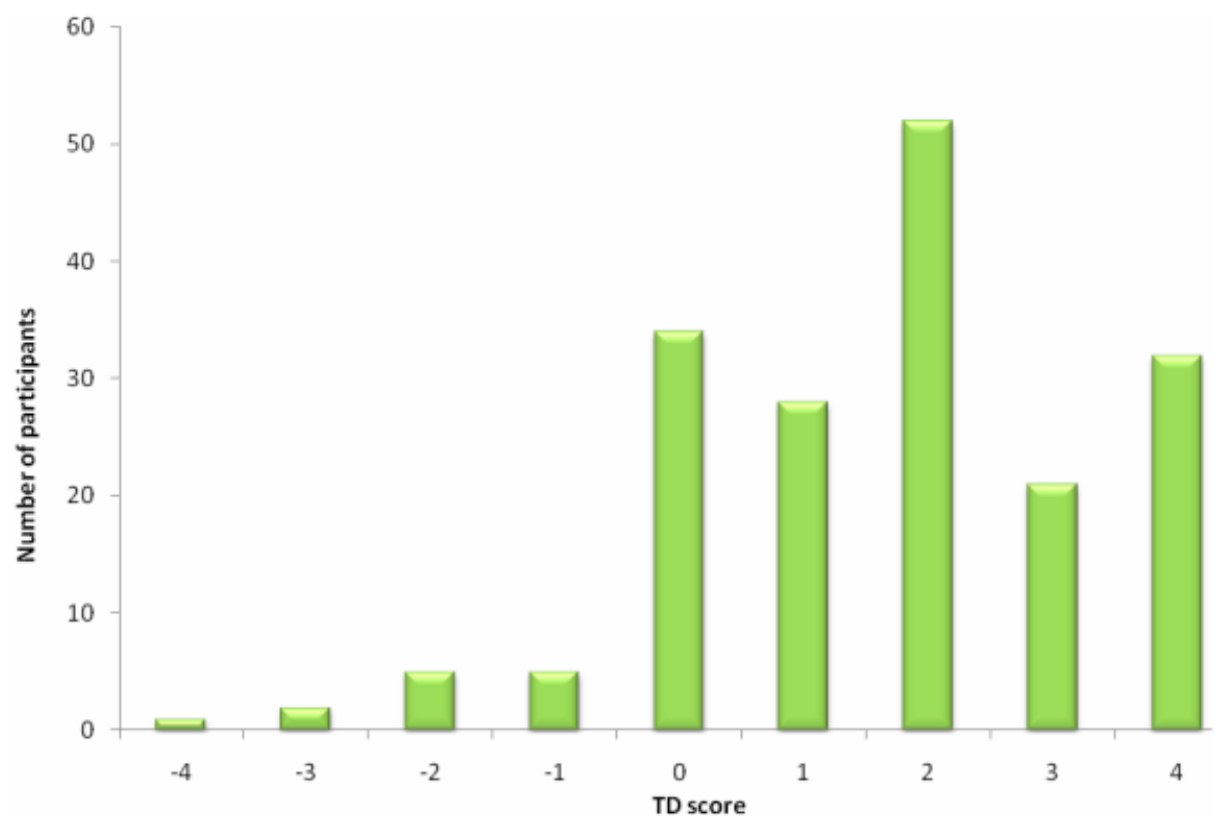

Figure 2: Distribution of TD Scores 


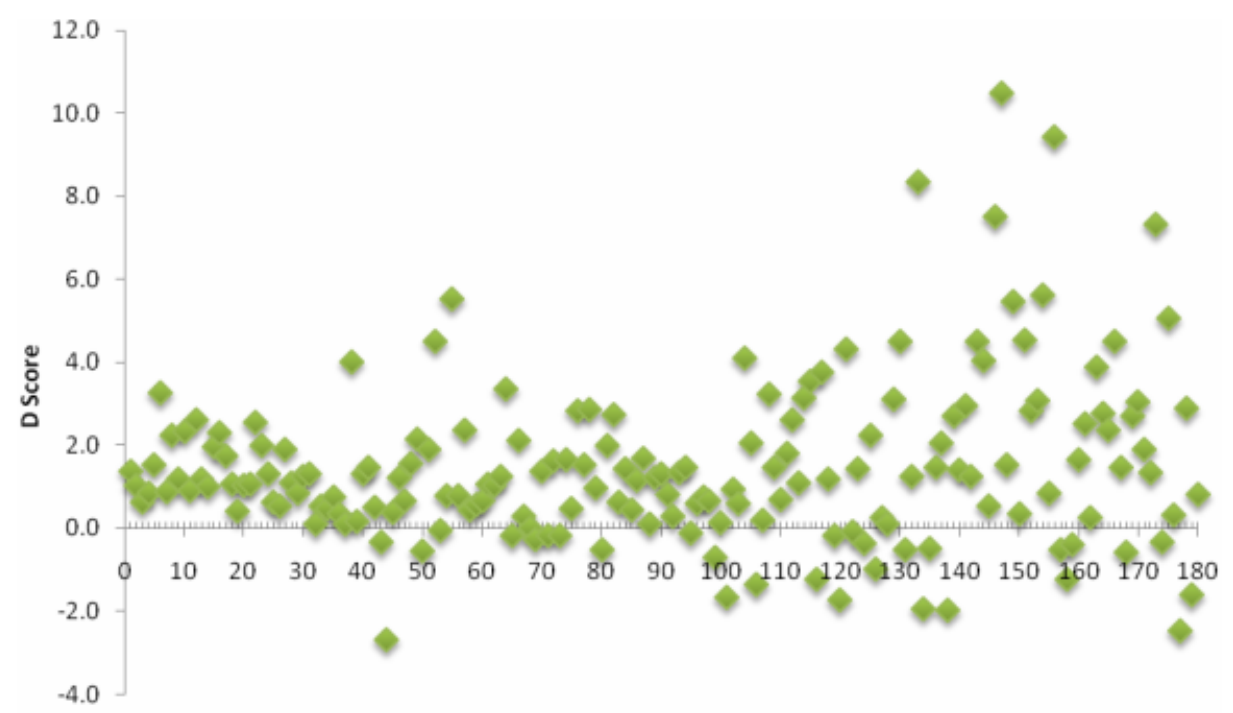

Participant Number

Figure 3: Distribution of D Scores

Table 3 outlines the correlations between explicit and implicit attitude measures. As expected, the explicit attitude measures were significantly correlated with each other $\left(r_{\mathrm{s}}=.559, \mathrm{n}=\right.$ $180, \mathrm{p}<0.01)$, but neither of the explicit measures were significantly correlated with the implicit attitude measure (Likert and D score $r_{\mathrm{s}}=-.013, \mathrm{n}=180$, n.s.; TD and D score $r_{\mathrm{s}}=$ $.006, \mathrm{n}=180, \mathrm{n} . \mathrm{s}$.$) .$

Table 3: Correlations between Explicit and Implicit Attitudes

\begin{tabular}{|l|l|c|c|c|}
\hline & & Likert Score & TD Score & D Score \\
\hline Likert Score & Correlation Coefficient & 1.000 & - & - \\
\hline & Sig. &. & - & - \\
\hline TD Score & Correlation Coefficient & $.559 * *$ & 1.000 & - \\
\hline & Sig. & .000 &. & - \\
\hline D Score & Correlation Coefficient & -.013 & .006 & 1.000 \\
\hline & Sig. & .865 & .934 &. \\
\hline
\end{tabular}

Figure 4 and figure 5 highlight the apparent discrepancies between explicit and implicit attitudes. Figure 4 shows the Likert scores plotted against the D scores. There are two subsets of participants who displayed some degree of divergence between their explicit and implicit attitudes (outlined with a dashed line). The first subset were those who explicitly stated they had no preference for high or low carbon footprint products (as indicated by a 3 on the Likert scale), but whose implicit scores indicated otherwise. This subset accounts for 46 out of the 
180 participants $(25.6 \%)$, of which 38 participants appeared to be greener than they explicitly stated when measured implicitly with positive (pro-low carbon) D scores $(\geq 0.2)$, and 8 participants who were implicitly less green than they explicitly stated with negative (prohigh carbon) D scores $(\leq-0.2)$. A second subset of 25 out of the 180 participants $(13.9 \%)$ explicitly stated they were very pro-low carbon with scores of 4 and 5 on the Likert scale, yet implicitly they were not as green as they explicitly stated. Within this subset, 10 participants had neutral implicit attitudes and 15 participants had negative D scores $(\leq-0.2)$, suggesting an implicit preference for high carbon.

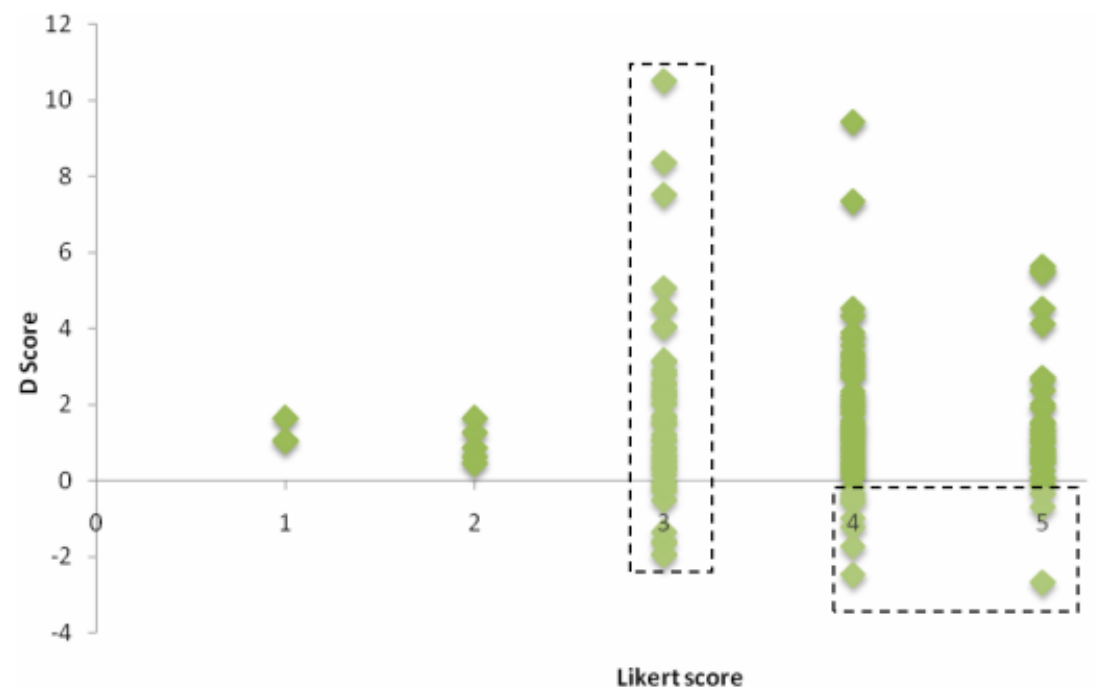

Figure 4: Distribution of Likert Scores and D Scores

The TD scores of the 180 participants are plotted against their D scores in figure 5. This distribution highlighted three subsets of participants with explicit and implicit attitude divergence. The first subset consisted of those who held neutral explicit attitudes (with TD scores of 0 ) but whose implicit attitude scores were not neutral, accounting for 29 out of the 180 participants (16.1\%). Of these, 26 participants were implicitly more pro-low carbon than their explicit attitudes would suggest with positive D scores $(\geq 0.2)$, and 3 participants appeared to be more pro-high carbon with negative D scores $(\leq-0.2)$. A second subset of 19 out of the 180 participants $(10.6 \%)$ explicitly stated they were pro-low carbon but had negative D scores $(\leq-0.2)$, which indicated an implicit preference for high carbon. A third and final subset of 11 out of the 180 participants $(6.1 \%)$ had a negative TD score, suggesting they were pro-high carbon, yet implicitly they appeared to be much greener with positive $\mathrm{D}$ scores $(\geq 0.2)$. 


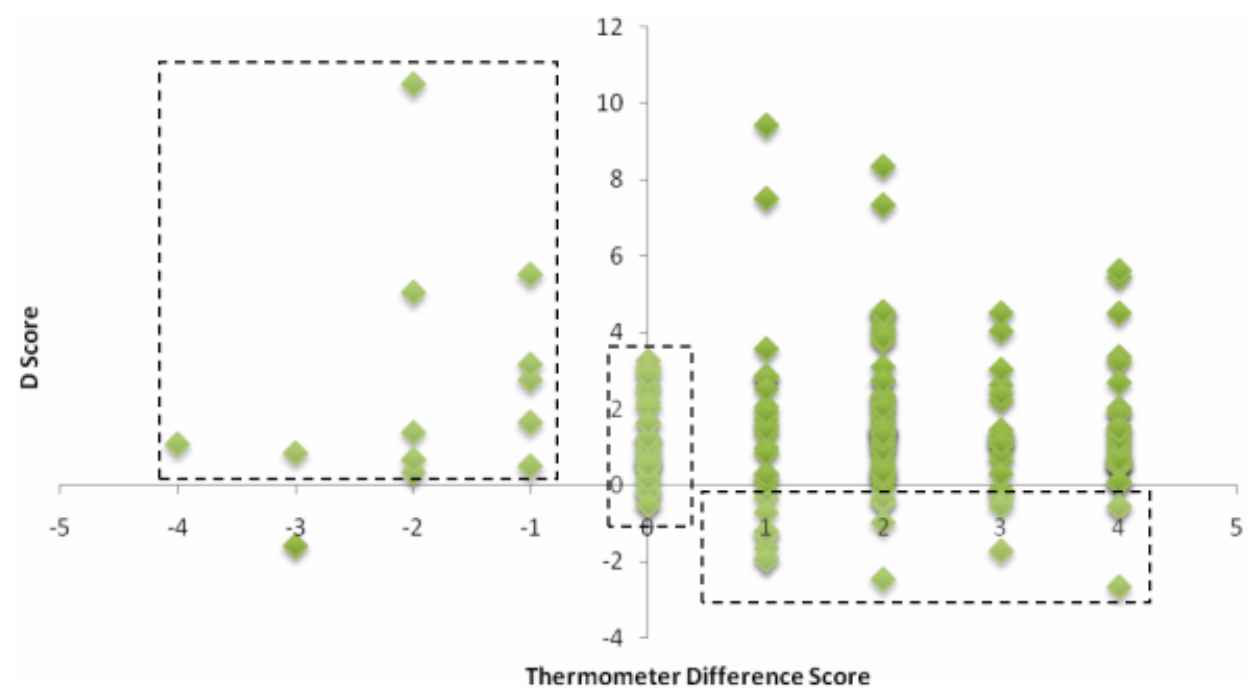

Figure 5: Distribution of TD Scores and D Scores

Another way of looking at the data is to focus on the extreme scores; in particular, those who explicitly stated they were strongly pro-low carbon. Of the 42 participants who scored 5 on the Likert scale ('I strongly prefer products with a low carbon footprint'), just over half (57.1\%) held convergent implicit attitudes with D scores $\geq 0.8$, suggesting a strong preference for low carbon products. This means that nearly half (42.9\%) of those who explicitly espoused the strongest pro-low carbon attitudes were not strongly pro-low carbon on the implicit measure, with D scores $<0.8$.

Of the 31 participants who had TD scores of 4 (suggesting a strong preference for low carbon), only $51.6 \%$ held implicit attitudes that were in line with their explicit attitudes (D scores $\geq 0.8$ ). So again, nearly half $(48.4 \%)$ of those who adamantly stated they were prolow carbon actually held implicit attitudes that were discrepant (D scores $<0.8$ ).

Clearly, a large proportion of people are exaggerating their green credentials, as evidenced by a high degree of dissociation between what people explicitly report in their attitude and what their implicit attitudes really are when it comes to green issues. Furthermore, the extent of this exaggeration is obviously greater than that originally anticipated by Beattie and Sale (2009). But what are the implications of these two different types of attitude for actual behavioural choice? 


\section{Study 2}

\section{Method}

\section{Participants}

Eighty university students were paid $£ 5$ for their involvement in the experiment and were rewarded with a goody bag. This is a subset of the 180 participants that formed the basis of the analysis in Study 1.

\section{Procedure}

Participants were asked to complete the carbon footprint IAT which included the two explicit attitude measures (Likert scale and feeling thermometer) and the IAT itself. After the participants completed the attitude tests, they had to choose a 'goody bag' containing either low (English apple, recycled pen, energy efficient light bulb) or high carbon footprint products (banana, biro, normal light bulb). These objects were laid out behind participants but remained covered during the attitude testing. Participants were invited to make a choice under one of two conditions - time pressure (TP), where they had to make an immediate choice encouraged by the experimenter, or no time pressure (no TP), where they had as much time as required to make their choice. The bags covering the products were removed by an assistant (blind to the scores on the attitude scales) and participants were asked to point to the goody bag of their choice. Participants were randomly assigned to the condition (TP/no TP) on consecutive trials.

\section{Results}

\section{Explicit Attitude Scores}

It is important to focus now on the distribution of scores within the subset of participants who were given the behavioural choice. The Likert scale showed a negatively skewed distribution with $15.0 \%$ of the participants scoring 5 ('strongly prefer low carbon') and $48.7 \%$ scoring 4 ('moderately prefer low carbon'). $31.3 \%$ showed no preference and only $5.0 \%$ showed any kind of preference for high carbon products. The modal score was 4 ('moderately prefer low carbon').

The TD results were also highly skewed towards pro-low carbon. $11.3 \%$ of participants showed the strongest preference $(+4)$ for products with low carbon footprint, an additional $71.2 \%$ showed some preference for low $(+1 /+2 /+3), 10.0 \%$ held a neutral attitude $(0)$ and only $7.5 \%$ showed a preference for high carbon products ( -4 to -1$)$. The modal response was +2 ('moderately prefer low carbon').

\section{Implicit Attitude Scores}

The IAT scores showed a very different distribution to that of the explicit measures, with relative 'peaks' at either end of the spectrum but with a general negative skew towards prolow carbon. The mode was $\geq+0.8$, which means 'strongly prefer low carbon'. Overall, $73.7 \%$ of participants had pro-low carbon D scores $(\geq+0.2), 21.3 \%$ had pro-high carbon $\mathrm{D}$ scores 
$(\leq-0.2)$ and $5 \%$ of participants showed no preference. One striking finding was that a significant number of participants $(12.5 \%)$ showed a strong implicit preference for high carbon $(\leq-0.8)$, despite their mean explicit scores indicating that they were in fact slightly pro-low carbon (3.4 on the Likert and 1.1 on the TD).

\section{Behavioural Choice}

Overall, $82.5 \%$ of participants chose the low carbon option and $17.5 \%$ chose the high carbon option. Of those participants who made their choice under time pressure, $74.4 \%$ chose the low carbon option and $25.6 \%$ chose the high carbon option. However, when under no time pressure, $90.2 \%$ of participants chose the low carbon option but only $9.8 \%$ chose the high.

The mean explicit and implicit attitude scores overall and across conditions are outlined in table 4. Across both conditions, the mean Likert score was 3.74, the mean TD score was 1.63 and the mean D score was 1.92 . When broken down by condition (TP versus no TP), the mean Likert score for participants in the time pressure condition was 3.80 , the mean thermometer difference score was 1.44 , and the mean D score was 1.89 . In the no time pressure condition, the mean Likert score was 3.68, the mean TD score was 1.81 and the mean D score was 1.96 .

Table 4: Mean Explicit and Implicit Attitude Scores Overall and Across Conditions

\begin{tabular}{|l|c|c|c|c|c|c|}
\hline & Overall Mean & SD & Mean TP & SD & Mean No TP & SD \\
\hline Likert Score & 3.74 & 0.78 & 3.80 & 0.83 & 3.68 & 0.72 \\
\hline TD Score & 1.63 & 1.55 & 1.44 & 1.94 & 1.81 & 1.05 \\
\hline D Score & 1.92 & 2.61 & 1.89 & 2.72 & 1.96 & 2.53 \\
\hline
\end{tabular}

Table 5 outlines the mean explicit and implicit scores of those who chose the high carbon option and those who chose the low carbon option. Whilst the mean Likert scores for those who chose high $(M=3.50)$ and those who chose low $(M=3.79)$ show little variation, as do the mean TD scores for those who chose high $(M=1.57)$ and those who chose low $(M$ $=1.64$ ), when we look at the mean D scores, it is clear that the mean D score of those who chose the high carbon option is considerably lower $(M=0.65)$ than the mean D score of those who chose the low carbon option $(M=2.19)$.

Table 5: Mean Explicit and Implicit Attitude Scores by Behavioural Choice

\begin{tabular}{|l|c|c|c|c|}
\hline & \multicolumn{4}{|c|}{ Behavioural Choice } \\
\hline & \multicolumn{2}{|c|}{ High Carbon } & \multicolumn{2}{c|}{ Low Carbon } \\
\hline & Mean & SD & Mean & SD \\
\hline Likert Score & 3.50 & 0.65 & 3.79 & 0.80 \\
\hline TD Score & 1.57 & 1.51 & 1.64 & 1.58 \\
\hline D Score & 0.65 & 2.19 & 2.19 & 2.62 \\
\hline
\end{tabular}


The mean explicit and implicit scores of participants who chose the high carbon products and participants who chose the low carbon products under each condition are outlined in table 6 . There is one striking set of numbers in this table. In the no time pressure condition, there was very little variation in explicit and implicit scores between those who chose the high carbon option and those who chose the low carbon option. For those who chose high, the mean Likert score was 3.50, the mean TD score was 2.00 and the mean D score was 1.98. For those who chose low, the mean Likert score was 3.70, the mean TD score was 1.78 and the mean D score was 1.96. However in the time pressure condition, whilst there was again very little variation in the mean scores of those who chose low with a mean Likert score of 3.90, a mean TD score of 1.47 and a mean D score of 2.50, when we look at the mean scores of those who chose the high carbon option, we find something very different. Whilst the mean Likert and TD scores were again fairly consistent, with scores of 3.50 and 1.40 respectively, the mean D score for those who chose the high carbon option was substantially lower at 0.12 (D scores of 2.50, 1.98 and 1.96 all indicate a strong preference for low carbon products, whereas a D score of 0.12 indicates no preference for either high or low carbon footprint products).

Table 6: Mean Implicit and Explicit Scores by Condition (TP/No TP) and Choice

\begin{tabular}{|l|c|c|c|c|c|c|c|c|}
\hline & \multicolumn{4}{|c|}{ Time Pressure (TP) } & \multicolumn{3}{c|}{ No Time Pressure (No TP) } \\
\hline & \multicolumn{2}{|c|}{ High } & \multicolumn{2}{c|}{ Low } & \multicolumn{2}{c|}{ High } & \multicolumn{2}{c|}{ Low } \\
\hline & Mean & SD & Mean & SD & Mean & SD & Mean & SD \\
\hline Likert Score & 3.50 & 0.71 & 3.90 & 0.86 & 3.50 & 0.58 & 3.70 & 0.74 \\
\hline TD Score & 1.40 & 1.78 & 1.47 & 2.00 & 2.00 & 0.00 & 1.78 & 1.11 \\
\hline D Score & 0.12 & 2.24 & 2.50 & 2.64 & 1.98 & 1.60 & 1.96 & 2.62 \\
\hline
\end{tabular}

\section{Correlations}

As expected, the explicit attitude measures were significantly correlated with one another $\left(r_{\mathrm{s}}=.578, \mathrm{n}=80, \mathrm{p}<0.01\right)$, whereas neither of the explicit measures were significantly correlated with the implicit attitude measure (Likert and D score $r_{\mathrm{s}}=.011, \mathrm{n}=80$, n.s.; TD and $\mathrm{D}$ score $r_{\mathrm{s}}=.040, \mathrm{n}=80$, n.s.).

Table 7: The Correlations between the Various Explicit and Implicit Measures

\begin{tabular}{|l|l|c|c|c|}
\hline & & Likert Score & TD Score & D Score \\
\hline Likert Score & Correlation Coefficient & 1.000 & - & - \\
\hline & Sig. &. & - & - \\
\hline TD Score & Correlation Coefficient & $.578^{* *}$ & 1.000 & - \\
\hline & Sig. & .000 &. & - \\
\hline D Score & Correlation Coefficient & .011 & .040 & 1.000 \\
\hline & Sig. & .919 & .722 &. \\
\hline ** Correlation is significant at the 0.01 level
\end{tabular}




\section{Logistic Regression}

A logistic regression was performed with behavioural choice as the dependent variable and Likert score, TD score, D score and condition as the predictor variables. A total of 80 cases were analysed and the full model was significantly reliable (chi-square $=11.40, \mathrm{df}=4, \mathrm{p}<$ 0.05). This model accounted for between $13.3 \%$ and $22.0 \%$ of the variance in behavioural choice between a high and low carbon goody bag. In total, $95.5 \%$ of the low carbon choices were successfully predicted and $14.3 \%$ of the predictions for the high carbon option were accurate. Overall, $81.2 \%$ of predictions were accurate. Table 9 gives coefficients, the Wald statistic with associated degrees of freedom and the probability values for each predictor variable.

The implicit measure (D score) and condition (time pressure versus no time pressure) were the only variables that reliably predicted actual behavioural choice (in the case of the implicit measure, the probability was approximately equal to 0.05 rather than reliably less than 0.05 ). The value of the coefficients reveal that a 1 point increase in $\mathrm{D}$ score is associated with a decrease in the odds of choosing the high carbon goody bag by a factor of .745 and that being under time pressure increases the odds of choosing a high carbon goody bag by a factor of 4.024. In other words, behavioural choice seems to connect to implicit but not explicit attitude scores. In addition, it seems that when under time pressure, participants are more likely to choose the high carbon alternative (if it is more closely aligned to their underlying implicit attitude).

Table 9: Logistic Regression Coefficients, Wald test and Odds Ration for Predictor Variables Included in the Model

\begin{tabular}{|l|c|c|c|c|c|}
\hline Predictor & B & Wald & df & Sig. & Exp(B) \\
\hline Implicit & -2.95 & 3.624 & 1 & .057 & .745 \\
\hline Explicit 1 (Likert) & -.905 & 2.759 & 1 & .097 & .405 \\
\hline Explicit 2 (TD) & .296 & 1.280 & 1 & .258 & 1.344 \\
\hline Condition (TP or No TP) & 1.392 & 4.067 & 1 & .044 & 4.024 \\
\hline Constant & .867 & .259 & 1 & .611 & 2.380 \\
\hline Note $\mathrm{R}^{2}=.133\left(\right.$ Cox \& Snell), .220 (Nagelkerke). Model $\mathrm{X}^{2}(4)=11.40, \mathrm{p}<0.05$ \\
\hline
\end{tabular}

\section{Discussion}

It is undeniable that climate change presents a serious risk to us all, and demands an urgent global response. Many people believe that consumers (rather than say governments) hold the key here by making green choices in their everyday patterns of consumption, provided they are given the opportunity to make these green choices in the first place (hence the growing provision of carbon footprint labels on products). Of course, this policy assumes that consumers already have the right underlying attitude to low carbon products. This, however, might be a potential pitfall. If consumers do not have the right attitude in the first place, then it is unlikely that any attempts to change consumer behaviour will actually affect consumer choice. Currently, we know very little about what the underlying attitudes to green 
products actually are (but see Beattie \& Sale, 2009; Beattie, 2010, for some exceptions). This study sought to measure both explicit and implicit attitudes to low carbon products (Study 1) and to determine which type of attitude (if any) predicted actual 'consumer choice' between a high or low carbon footprint goody bag in an experimental situation (Study 2). An exploratory variable that was also included was time pressure, chosen partly for theoretical reasons, namely that time pressure may well influence the predictive value of implicit attitudes, and partly for practical reasons, namely that supermarket shopping often occurs under considerable time pressure with little time devoted to the consideration of individual products (see Gelperowic \& Beharrell, 1994).

In Study 1, it was found that many people do seem to display a degree of attitudinal dissociation with respect to carbon footprint. Of the 42 participants who scored 5 on the Likert scale ('I strongly prefer products with a low carbon footprint'), just over half (57.1\%) held convergent implicit attitudes with $\mathrm{D}$ scores $\geq 0.8$, suggesting a strong implicit preference for low carbon products. This means that nearly half (42.9\%) of those who explicitly espoused the strongest pro-low carbon attitudes (expressed in terms of preference) were not strongly pro-low carbon on the implicit measure (D scores $<0.8$ ). Similarly, of the 31 participants who had TD scores of 4 (suggesting a strong explicit preference for low carbon in terms of feelings), 51.6\% held implicit attitudes that were in line with their explicit attitudes (D scores $\geq 0.8$ ). So again, nearly half ( $48.4 \%$ ) of those who adamantly stated they were pro-low carbon actually held implicit attitudes that were discrepant (D scores $<0.8$ ). Clearly, a large proportion of people are exaggerating their green credentials, and the extent of this exaggeration is obviously greater than that anticipated by Beattie and Sale (2009).

In Study 2, it was also found that there was little relationship between explicit and implicit scores. Different subsets of the sample showed a range of types of dissociation in their attitudes (as with Study 1). But perhaps even more importantly, it was found that none of the explicit measures significantly predicted choice of the high or low carbon products in a forced choice procedure. However, the implicit attitude measure (the D score) did. Those who were pro-low carbon, as revealed by the IAT, were significantly more likely to choose the low carbon footprint goody bag. Explicit measures, however, were not a significant predictor. The implication of this finding is clear; in terms of predicting patterns of behaviour, we simply cannot rely on what people are explicitly stating in this domain. Thus, one might argue, if we are to genuinely produce a green revolution, then the critical concept of implicit attitudes must be kept firmly in focus. It may well be a matter of urgency to consider how to augment implicit attitudes to green products and, in addition, to ensure that these implicit attitudes translate to actual consumer behaviour, for example, by designing carbon footprint symbols that can impact on the implicit system. One potentially important practical step in this regard may be to think about the design of carbon labels. The detailed carbon footprint information currently on labels might work if consumer choice is a slow, reflective process directed by explicit attitudes (currently there is little visual attention to these carbon labels in the normal 5-10 second viewing frame, see Beattie, McGuire \& Sale, 2010). However, if consumer choice is much more automatic and unconscious then we may need a different labelling system that can impinge on more automatic processes. For example, we may need to use something like a traffic light approach, with red symbolising 'high carbon footprint' or 'danger' (hence producing relatively more right frontal cortical activation, see Elliot, Maier, Markus, Moller, Friedman \& Meinhardt, 2007; Beattie, 2011). Traffic light signals 
might well influence consumer choice guided by these implicit processes in a way that the (very well meaning) current system does not.

Study 2 also revealed that the condition under which the behavioural choice was made (i.e. under time pressure or no time pressure) significantly predicted choice so that, when under time pressure, people were more likely to choose the high carbon footprint option (the mean D score of those choosing the high carbon option under time pressure was 0.12 , which was the lowest mean D score and therefore the least pro-low carbon footprint implicit attitude in the entire sample, suggesting that under time pressure implicit attitudes influenced behaviour). This finding has implications for supermarket shopping which, unfortunately (from this point of view), is an activity often conducted under a great deal of time pressure (see also Southerton, 2003). Our research would suggest that the likelihood of consumers actually choosing the 'greener option' would be significantly reduced under these conditions if their implicit attitudes were not sufficiently pro-low carbon in the first place.

Of course, we just used one type of behavioural choice in this study, and a choice with no economic consequences whatsoever for the consumer. Future research must determine the generality of this effect in a much more representative (and real) consumer domain. Indeed, this will form the basis of some new research, already planned in detail, in which we will analyse the relationship between explicit and implicit attitudes and actual consumer choice as revealed through the Tesco Clubcard data (under the Sustainable Consumption Institute's Flagship Project 1: 'Modelling Consumer Behaviour' at the University of Manchester). The present study was also extremely limited in terms of the size of the sample used, especially for the behavioural choice procedure. Again, this will be rectified in the new research where the sample size will increase dramatically to 60,000 . Finally, most of the behavioural choices in our study were for the low carbon footprint goody bag, which again produced an odd distribution of data (it started to shift towards the high carbon option only under the conditions already outlined). In real supermarkets the distribution and the resulting pressures will be quite different.

But despite the obvious limitations of the present study, including the nature of the consumer behaviours studied and the highly restricted sample size, we would humbly suggest that we now have at least suggestive evidence that the nature of our implicit attitudes to green products and their influence on consumer choice may well be urgent considerations for us all, and not just for purely scientific reasons. Some scientists might well argue that our very future depends upon it.

\section{Acknowledgements}

We would like to thank Tesco for their generous financial support of this research through the Sustainable Consumption Institute at the University of Manchester and we would like to express our gratitude to $\mathrm{Yu} \mathrm{Li}$ for his invaluable assistance in programming the IAT. We would also like to thank two anonymous referees for their very helpful comments on an earlier draft of this paper. 


\section{References}

Beattie, G. (2010). Why aren't we saving the planet? A psychologist's perspective. London and New York: Routledge.

Beattie, G. (2011). Get the edge: How simple changes will transform your life. London: Headline.

Beattie, G., McGuire, L., \& Sale, L. (2010). Do we actually look at the carbon footprint of a product in the initial few seconds? An experimental analysis of unconscious eye movements. The International Journal of Environmental, Cultural, Economic and Social Sustainability, 6, 4766.

Beattie, G., \& Sale, L. (2009). Explicit and implicit attitudes to low and high carbon footprint products. The International Journal of Environmental, Cultural, Economic and Social Sustainability, 5, 191-206.

Brunel, F.F., Tietje, B.C., \& Greenwald, A.G. (2004). Is the Implicit Association Test a valid and valuable measure of implicit consumer social cognition? Journal of Consumer Psychology, $14,385-404$.

Chaiken, S., \& Trope, Y. (eds). (1999). Dual process theories in social psychology. New York: Guilford. Cohen, J. (1988). Statistical power analysis for the behavioral sciences. Hillsdale, NJ: Erlbaum.

Downing, P., \& Ballantyne, J. (2007). Tipping point or turning point? Social marketing and climate change. (Online). Ipsos MORI. http://www.ipsosmori.com/_assets/pdfs/turning\%20point\% 20or\%20tipping\%20point.pdf.

Elliot, A.J., Maier, M.A., Moller, A.C., Friedman, R., \& Meinhardt, J. (2007). Color and psychological functioning: The effect of red on performance attainment. Journal of Experimental Psychology, 136, 154-68.

Forum for the Future. (2007). Retail futures 2022: Scenarios for the future of UK retail and sustainable development. (Online). Forum for the Future. http://www.forumforthefuture.org/retail-futures2022.

Friese, M., Hofmann, W., \& Wänke, M. (2008). When impulses take over: Moderated predictive validity of explicit and implicit attitude measures in predicting food choice and consumption behaviour. British Journal of Social Psychology, 47, 397-419.

Friese, M., Wänke, M., \& Plessner, H. (2006). Implicit consumer preferences and their influence on product choice. Psychology and Marketing, 23, 727-740.

Gelperowic, R., \& Beharrell, B. (1994). Healthy food products for children: packaging and mothers' purchase decisions. British Food Journal, 96, 4-8.

Gibson, B. (2008). Can evaluative conditioning change attitudes toward mature brands? New evidence from the implicit association test. Journal of Consumer Research, 35, 178-188.

Gifford, R. (2008). Psychology's essential role in alleviating the impacts of climate change. Canadian Psychology, 49, 273-280.

Greenwald, A.G., \& Banaji, M.R. (1995). Implicit social cognition: Attitudes, selfesteem, and stereotypes. Psychological Review, 102, 4-27.

Greenwald, A.G., McGhee, D.E., \& Schwartz, J.L.K. (1998). Measuring individual differences in implicit cognition: The Implicit Association Test. Journal of Personality and Social Psychology, 74, 1464-80.

Greenwald, A.G., \& Nosek, B.A. (2008). Attitudinal dissociation: What does it mean? In R.E. Petty, R.H. Fazio, and P. Brinol (eds.). Attitudes: Insights from the new implicit measures. Hillsdale, NJ: Erlbaum, pp.65-82.

Greenwald, A.G., Nosek, B.A., \& Banaji, M.R. (2003). Understanding and using the Implicit Association Test: 1. An improved scoring algorithm. Journal of Personality and Social Psychology, 85, 197-216.

Greenwald, A.G., Poehlman, T.A., Uhlmann, E., \& Banaji, M.R. (2009). Understanding and using the implicit association test: III. Meta-analysis of predictive validity. Journal of Personality and Social Psychology, 97, 17-41. 
Gregg, A. P. (2008). Oracle of the unconscious or deceiver of the unwitting? The Psychologist, 21, 762-66.

Hofmann, W., \& Friese, M. (2008). Impulses got the better of me: Alcohol moderates the influence of implicit attitudes toward food cues on eating behaviour. Journal of Abnormal Psychology $117,420-427$.

Hofmann, W., Gawronski, B., Gschwendner, T., Le, H., \& Schmitt, M. (2005). A meta-analysis on the correlation between the Implicit Association Test and explicit self-report measures. Personality and Social Psychology Bulletin, 31, 1369-85.

Hofmann, W., Rauch, W., \& Gawronski, B. (2007). And deplete us not into temptation: Automatic attitudes, dietary restraint, and self-regulatory resources as determinants of eating behaviour. Journal of Experimental Social Psychology, 43, 497-504.

Karpinski, A., \& Hilton, J.L. (2001). Attitudes and the Implicit Association Test. Journal of Personality and Social Psychology, 81, 774-788.

Karpinski, A., \& Steinman, R.B. (2006). The single category Implicit Association Test as a measure of implicit social cognition. Journal of Personality and Social Psychology, 91, 16- 32.

Karpinski, A., Steinman, R.B., \& Hilton, J.L. (2005). Attitude importance as a moderator of the relationship between implicit and explicit attitude measures. Personality and Social Psychology Bulletin, 31, 949-962.

Maison, D., Greenwald, A.G., \& Bruin, R.H. (2001). The Implicit Association Test as a measure of consumer attitudes. Polish Psychological Bulletin, 2, 61-79.

Maison, D., Greenwald, A.G., \& Bruin, R.H. (2004). Predictive validity of the Implicit Association Test in studies of brands, consumer attitudes and behaviour. Journal of Consumer Psychology, $14,405-415$.

Nosek, B.A. (2005). Moderators of the relationship between implicit and explicit evaluation. Journal of Experimental Psychology: General, 134, 565-84.

Nosek, B.A., \& Hansen, J.J. (2008). The associations in our heads belong to us: Searching for attitudes and knowledge in implicit evaluation. Cognition and Emotion, 22, 553-94.

Olson, M.A., \& Fazio, R.H. (2004). Reducing the influence of extra-personal associations on the Implicit Association Test: Personalizing the IAT. Journal of Personality and Social Psychology, $86,653-667$.

Rundh, B. (2007). The multi-faceted dimension of packaging: Marketing logistic or marketing tool? British Food Journal, 107, 670-84.

Scarabis, M., Florack, A., \& Gosejohann, S. (2006). When consumers follow their feelings: The impact of affective or cognitive focus on the basis of consumers' choice. Psychology and Marketing, 23, 1005-1036.

Southerton, D. (2003). Squeezing Time: Allocating practices, co-ordinating networks and scheduling society. Time \& Society, 12, 5-25.

Stern, N.H. (2006). The economics of climate change: The Stern review. Cambridge: Cambridge University Press.

Sustainable Consumption Institute. (2009). Consumers, business and climate change. (Online.) The University of Manchester Sustainable Consumption Institute.

http://www.sci.manchester.ac.uk/medialibrary/copenhagenpaper.pdf.

Sustainable Consumption Roundtable. (2006). I will if you will: Towards sustainable consumption. (Online). Sustainable Development Commission. http://www.sd-commission.org.uk/publications/downloads/I_Will_If_You_Will. Pdf.

Swanson, J.E., Rudman, L.A., \& Greenwald, A.G. (2001). Using the Implicit Association Test to investigate attitude-behavior consistency for stigmatized behaviour. Cognition and Emotion, $15,207-230$.

Vantomme, D., Geuens, M., De Houwer, J., \& De Pelsmacker, P. (2005). Implicit attitudes toward green consumer behaviour. Psychologica Belgica, 45, 217-39. 
Walker, G., \& King, D. (2008). The hot topic: How to tackle global warming and still keep the lights on. London: Bloomsbury.

Wilson, T., Lindsey, S., \& Schooler, T.Y. (2000). A model of dual attitudes. Psychological Review, 107, 101-26.

World Bank. (2010). World Development Report 2010: Development and climate change. (Online) http://siteresources.worldbank.org/INTWDR2010/Resource s/5287678-12260145279 53/WDR10-Full-Text.pdf.

Zeithaml, V.A. (2008). Consumer perceptions of price, quality, and value: a means-end model and synthesis of evidence. Journal of Marketing, 52, 2-22.

\section{About the Authors}

Prof. Geoffrey Beattie

Geoffrey Beattie is Professor of Psychology and Head of the School of Psychological Sciences at the University of Manchester. He is also a Professorial Research Fellow of the Sustainable Consumption Institute recently established at the University. He obtained his $\mathrm{PhD}$ in Psychology from the University of Cambridge (Trinity College) and he is a Fellow of the British Psychological Society (BPS). He was awarded the Spearman Medal by the BPS for "published psychological research of outstanding merit". In 2005 Geoffrey was President of the Psychology Section of the British Association for the Advancement of Science. He has published 17 books many of which have either won or been short-listed for major international or national prizes and he has published more than a hundred academic articles in journals like Nature, Semiotica, the British Journal of Psychology and the Journal of Language and Social Psychology.

\section{Laura Sale}

Laura Sale is a Research Assistant in the School of Psychological Sciences at the University of Manchester and is part of a research team at the Sustainable Consumption Institute (SCI) established at the University of Manchester, and sponsored by Tesco. Laura is currently working with Professor Geoffrey Beattie under the Sustainable Consumer Behaviours and Lifestyles theme at the SCI with a particular focus on implicit and explicit attitudes in the context of sustainable consumption. This research aims to generate new insights into the psychological variables underpinning low carbon footprint choices and offer specific recommendations on how these core psychological variables can be targeted in order to increase the salience of carbon footprint information in the consumer environment. 


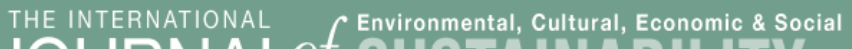

\section{Editors}

Amareswar Galla, The University of Queensland, Brisbane, Australia.

Bill Cope, University of Illinois at Urbana-Champaign, USA.

\section{Editorial Advisory Board}

Shamsul Nahar Abdullah, University of Malaysia Terengganu, Malaysia.

Wan Izatul Asma, University of Malaysia Terengganu, Malaysia.

Dang Van Bai, Ministry of Culture and Information, Vietnam.

Michael Cameron, University of Waikato, Hamilton, New Zealand.

Richard M. Clugston, University Leaders for a Sustainable Future, Washington, USA. John Dryzek, Australian National University, Canberra, Australia.

Dato'Abdul Razak Dzulkifli, Universiti Sains Malaysia, Malaysia.

Robyn Eckersley, University of Melbourne, Melbourne, Australia.

Steven Engelsman, Rijksmuseum voor Volkenkunde, Leiden, The Netherlands.

John Fien, RMIT University, Melbourne, Australia.

Suzanne Grant, University of Waikato, Hamilton, New Zealand.

Steve Hamnett, University of South Australia, Adelaide, Australia.

Paul James, RMIT University, Melbourne, Australia.

Mary Kalantzis, University of Illinois, Urbana-Champaign, USA.

Nik Fuad Nik Mohd Kamil, University of Malaysia Terengganu, Malaysia.

Lily Kong, National University of Singapore, Singapore.

Thangavelu Vasantha Kumaran, University of Madras, Chennai, India.

Jim McAllister, Central Queensland University, Rockhamptom, Australia.

Nik Hashim Nik Mustapha, University of Malaysia Terengganu, Malaysia.

Helena Norberg-Hodge, The International Society for Ecology and Culture (ISEC), UK.

Peter Phipps, RMIT University, Melbourne, Australia.

Koteswara Prasad, University of Madras, Chennai, India.

Behzad Sodagar, University of Lincoln, Brayford Pool, United Kingdom. Judy Spokes, Cultural Development Network, Melbourne, Australia.

Manfred Steger, Illinois State University, Normal, USA; RMIT University, Melbourne, Australia.

Douglas Worts, LEAD Fellow (Leadership for Environment and Development), Toronto, Canada

David Wood, University of Waterloo, Waterloo, Canada.

Lyuba Zarsky, RMIT University, Melbourne, Australia; Tufts University, Medford, USA.

Please visit the Journal website at http://www.Sustainability-Journal.com for further information about the Journal or to subscribe. 


\section{The Sustainability Community}

This is a knowledge community brought together by a common concern for sustainability in an holistic perspective, where environmental, cultural, economic and social concerns intersect. The community interacts through an innovative, annual face-to-face conference, as well as year-round virtual relationships in a weblog, peer reviewed journal and book imprint - exploring the affordances of the new digital media. Members of this knowledge community include academics, researchers, policy makers, public servants, members of government and non-government organisations, consultants, educators and research students.

\section{Conference}

Members of the Sustainability Community meet at the International Conference on Environmental, Cultural, Economic and Social Sustainability, held annually in different locations around the world.

The Conference was held at the University of Waikato, Hamilton, New Zealand in 2011; University of Cuenca, Cuenca, Ecuador in 2010; University of Technology Mauritius, Mauritius in 2009; Universiti Malaysia Terengganu, Kuala Terengganu, Malaysia in 2008; University of Madras, Chennai, India in 2007; Hanoi and Ha Long Bay, Vietnam in 2006; and the University of Hawai'i at Manoa, Island of Oahu, Hawai'i, USA in 2005. In 2012, the Conference will be held at the Robson Square, University of British Columbia, Vancouver, Canada.

Our community members and first time attendees come from all corners of the globe. Intellectually, our interests span the breadth of the various sustainability disciplines and fields of study. The Conference is a site of critical reflection, both by leaders in the field and emerging scholars. Those unable to attend the Conference may opt for virtual participation in which community members can either submit a video and/or slide presentation with voice-over, or simply submit a paper for peer review and possible publication in the Journal.

Online presentations can be viewed on YouTube.

\section{Publishing}

The Sustainability Community enables members to publish through three media. First, by participating in the Sustainability Conference, community members can enter a world of journal publication unlike traditional academic publishing forums - a result of the responsive, non-hierarchical and constructive nature of the peer review process. The International Journal of Environmental, Cultural, Economic and Social Sustainability provides a framework for double-blind peer review, enabling authors to publish into an academic journal of the highest standard.

The second publication medium is through the book series On Sustainability, publishing cutting edge books in print and electronic formats. Publication proposals and manuscript submissions are welcome.

The third major publishing medium is our news blog, constantly publishing short news updates from the Sustainability Community, as well as major developments in the various disciplines of sustainability. You can also join this conversation at Facebook and Twitter or subscribe to our email Newsletter. 


\section{Common Ground Publishing Journals}

\begin{tabular}{|c|c|}
\hline $\begin{array}{l}\text { AGING } \\
\text { Aging and Society: An Interdisciplinary Journal } \\
\text { Website: http://AgingAndSociety.com/journal/ }\end{array}$ & $\begin{array}{c}\text { ARTS } \\
\text { The International Journal of the Arts in Society. } \\
\text { Website: www.Arts-Journal.com }\end{array}$ \\
\hline $\begin{array}{c}\text { BOOK } \\
\text { The International Journal of the Book } \\
\text { Website: www.Book-Journal.com }\end{array}$ & $\begin{array}{c}\text { CLIMATE CHANGE } \\
\text { The International Journal of Climate Change: } \\
\text { Impacts and Responses } \\
\text { Website: www.Climate-Journal.com }\end{array}$ \\
\hline $\begin{array}{c}\text { CONSTRUCTED ENVIRONMENT } \\
\text { The International Journal of the } \\
\text { Constructed Environment } \\
\text { Website: www.ConstructedEnvironment.com/journal }\end{array}$ & $\begin{array}{c}\text { DESIGN } \\
\text { Design Principles and Practices: } \\
\text { An International Journal } \\
\text { Website: www.Design-Journal.com }\end{array}$ \\
\hline $\begin{array}{c}\text { DIVERSITY } \\
\text { The International Journal of Diversity in } \\
\text { Organizations, Communities and Nations } \\
\text { Website: www.Diversity-Journal.com }\end{array}$ & $\begin{array}{l}\text { FOOD } \\
\text { Food Studies: An Interdisciplinary Journal } \\
\text { Website: http://Food-Studies.com/journal/ }\end{array}$ \\
\hline $\begin{array}{c}\text { GLOBAL STUDIES } \\
\text { The Global Studies Journal } \\
\text { Website: www.GlobalStudiesJournal.com }\end{array}$ & $\begin{array}{c}\text { HEALTH } \\
\text { The International Journal of Health, } \\
\text { Wellness and Society } \\
\text { Website: www.HealthandSociety.com/journal }\end{array}$ \\
\hline $\begin{array}{c}\text { HUMANITIES } \\
\text { The International Journal of the Humanities } \\
\text { Website: www. Humanities-Journal.com }\end{array}$ & $\begin{array}{c}\text { IMAGE } \\
\text { The International Journal of the Image } \\
\text { Website: www.Onthelmage.com/journal }\end{array}$ \\
\hline $\begin{array}{l}\text { LEARNING } \\
\text { The International Journal of Learning. } \\
\text { Website: www.Learning-Journal.com }\end{array}$ & $\begin{array}{c}\text { MANAGEMENT } \\
\text { The International Journal of Knowledge, } \\
\text { Culture and Change Management. } \\
\text { Website: www.Management-Journal.com }\end{array}$ \\
\hline $\begin{array}{c}\text { MUSEUM } \\
\text { The International Journal of the Inclusive Museum } \\
\text { Website: www.Museum-Journal.com }\end{array}$ & $\begin{array}{c}\text { RELIGION AND SPIRITUALITY } \\
\text { The International Journal of Religion and } \\
\text { Spirituality in Society } \\
\text { Website: www.Religion-Journal.com }\end{array}$ \\
\hline $\begin{array}{c}\text { SCIENCE IN SOCIETY } \\
\text { The International Journal of Science in Society } \\
\text { Website: www.ScienceinSocietyJournal.com }\end{array}$ & $\begin{array}{c}\text { SOCIAL SCIENCES } \\
\text { The International Journal of Interdisciplinary } \\
\text { Social Sciences } \\
\text { Website: www.SocialSciences-Journal.com }\end{array}$ \\
\hline $\begin{array}{c}\text { SPACES AND FLOWS } \\
\text { Spaces and Flows: An International Journal of } \\
\text { Urban and ExtraUrban Studies } \\
\text { Website: www.SpacesJournal.com }\end{array}$ & $\begin{array}{c}\text { SPORT AND SOCIETY } \\
\text { The International Journal of Sport and Society } \\
\text { Website: www.sportandsociety.com/journal }\end{array}$ \\
\hline $\begin{array}{c}\text { SUSTAINABILITY } \\
\text { The International Journal of Environmental, Cultural, } \\
\text { Economic and Social Sustainability } \\
\text { Website: www.Sustainability-Journal.com }\end{array}$ & $\begin{array}{c}\text { TECHNOLOGY } \\
\text { The International Journal of Technology, } \\
\text { Knowledge and Society } \\
\text { Website: www.Technology-Journal.com }\end{array}$ \\
\hline $\begin{array}{c}\text { UBIQUITOUS LEARNING } \\
\text { Ubiquitous Learning: An International Journal } \\
\text { Website: www.ubi-learn.com/journal/ }\end{array}$ & $\begin{array}{l}\text { UNIVERSITIES } \\
\text { Journal of the World Universities Forum } \\
\text { Website: www.Universities-Journal.com }\end{array}$ \\
\hline
\end{tabular}

